\title{
Analysis of Critical Thinking Skills of Middle School Students on Environmental Pollution Materials
}

\author{
Nurhayati $^{*}$, Rudiana Agustini ${ }^{2}$, Elok Sudibyo ${ }^{3}$ \\ 1,2,3Universitas Negeri Surabaya, Surabaya, Indonesia
}

\begin{tabular}{|c|c|}
\hline 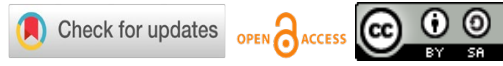 & DOI: https://doi.org/10.46245/ijorer.v3i1.186 \\
\hline Sections Info & \multirow{11}{*}{$\begin{array}{l}\text { The ability that should be possessed by students is not only limited to } \\
\text { learning outcomes by receiving knowledge. Critical thinking skills need to be } \\
\text { a provision to face the demands of the } 21 \text { st century. Science is a subject that } \\
\text { can not be separated from the critical thinking skills. One of the scientific } \\
\text { materials is environmental pollution. Research has been carried out that aims } \\
\text { to determine the students' initial critical thinking skills. The subjects used in } \\
\text { the study were students of Junior High School Plus Nurul Hikmah. This type } \\
\text { of research is descriptive method. The data collection instrument used a test. } \\
\text { The results showed that the average critical thinking skillsof students was } \\
\text { low category. The achievement of the indicator elementary clarification } \\
\text { scored } 43 \% \text { in the medium category, while the indicator the basis for the } \\
\text { decision scored } 39 \% \text { in the low category. The achievement of the indicator } \\
\text { inference obtained } 46 \% \text { in the medium category. The indicator advances } \\
\text { clarification scored } 43 \% \text { in the medium category, while the indicator } \\
\text { supposition and integration scored } 29 \% \text { in the low category. In general, } \\
\text { category for students critical thinking skills in all indicators are low. In } \\
\text { general, criteria for students critical thinking skills in all indicators are low. }\end{array}$} \\
\hline Article hist & \\
\hline Submitted: December 23, 2021 & \\
\hline Final Revised: January 6, 2022 & \\
\hline January 7, 2022 & \\
\hline Published: January 31, 2022 & \\
\hline & \\
\hline Critical Thinking Skills & \\
\hline Environmental Pollution & \\
\hline & \\
\hline & \\
\hline
\end{tabular}

\section{INTRODUCTION}

Science and technology are experiencing very significant developments causing a lot of competition in several aspects of life, including the education aspect. Efforts to address these conditions require a quality education process. The education sector should be able to educate students so that they can develop according to their times. This means providing provisions for students not from the experience of each teacher, but according to the aspects that students need in the future (Syahrul et al., 2021). This is intended so that students can participate in society constructively and productively in the future, especially the various kinds of demands in the 21st century.

In the 21st century, there were significant changes and developments, which is often referred to as the era of the industrial revolution 4.0. This change in situation and conditions requires the readiness of qualified Human Resources (HR) so that they can adapt and be able to compete on an international scale. The success of a country in responding to the industrial revolution 4.0 cannot be separated from the role of quality teachers in educational institutions. Education in the revolution era 4.0 is a response to the demands of the revolution marked by the alignment between technology and humans to create new opportunities with new innovations and creativity that continues to grow (Rahman \& Nuryana, 2019). Innovation is also able to disrupt existing elements and even replace existing technology. To keep up with technological developments, quality human resources are needed. Based on this, to be able to have quality human resources, quality education is needed (Suciono et al., 2021). The goal of education in the 21st century is expected to be able to obtain the output of 
students who are competent in utilizing information and communication. In addition, that is improving higher-order thinking skills (Susilawati et al., 2020). The curriculum applied in schools is expected to contain the competencies contained in the demands of the 21st century, including creativity, problem-solving skills, communication and collaboration skills, and critical thinking skills. The ability to think critically is one of the demands that must be met in current learning (Pradana et al., 2017).

Critical thinking is an evaluative ability that shows the human ability to see the gap between reality and truth by referring to ideals, as well as being able to evaluate and analyze. Critical thinking refers to the desired learning concept and has an important role as well as educational goals. The quality of critical thinking has different implications (Nurlailah \& Hamdu, 2021). Critical thinking is defined as skills in examining several assumptions or opinions, distinguishing hidden values, evaluating evidence, and assessing conclusions (Fuad et al., 2017). Phenomena that are often encountered in life often involve related evidence that gives rise to many assumptions. Based on this, higher-order thinking skills are an alternative in filtering and examining the existing evidence. Various assumptions that were triggered by several parties and sources need to know the hidden values and evaluate them so that an agreed conclusion can be obtained. This is an activity in critical thinking.

The ability to think critically has become one of the educational goals that must be achieved because critical thinking as one of the higher-order thinking skills has played a role in moral, social, and scientific development (Kartika et al., 2020). In the process of learning science, it is very important to train students' critical thinking skills under the Regulation of the Minister of Education of the Republic of Indonesia number 41 of 2007. This regulation is about standard processes for educational units. The obligation to improve thinking skills in teaching and learning activities is contained in the regulation (Luzyawati, 2018). Students' thinking ability to meet the demands of the 21st century is very important to be developed to be able to respond to the situation scientifically and based on logic. A critical thinker will be able to analyze and evaluate any new information he receives (Nuryanti et al., 2018).

The ability to think critically is a priority in education. This brings critical thinking to the meaning of the process of analyzing, evaluating, synthesizing, finding conclusions, as well as feedback or reflection that allows a person to make assumptions and judgments about something, both in the classroom and in everyday life (Utami at al., 2017). The ability to think critically certainly cannot be separated from the subject of Natural Sciences (IPA). Critical thinking is very important to be applied in science learning with the aim that students can apply scientific concepts and make responsible decisions when entering society in the future (Santos, 2017). Critical thinking skills can be trained for students through the learning process. The learning process will be easier to achieve maximum goals if the students' initial abilities are known, namely their initial critical thinking abilities (Ridho et al., 2020). Based on this, the researcher intends to find out and analyze students' initial critical thinking abilities.

\section{RESEARCH METHOD}

The type of research that has been carried out is descriptive with a quantitative approach. This study describes the critical thinking skills of junior high school students. Descriptive research explains the actual conditions in which there are no independent variables or manipulation variables (Arikunto, 2013). The data described is using data from the test results of students' critical thinking skills on environmental pollution 
material. This descriptive study aims to provide a clearer picture of students' critical thinking skills. The flow of the research carried out is shown in the following Figure 1.

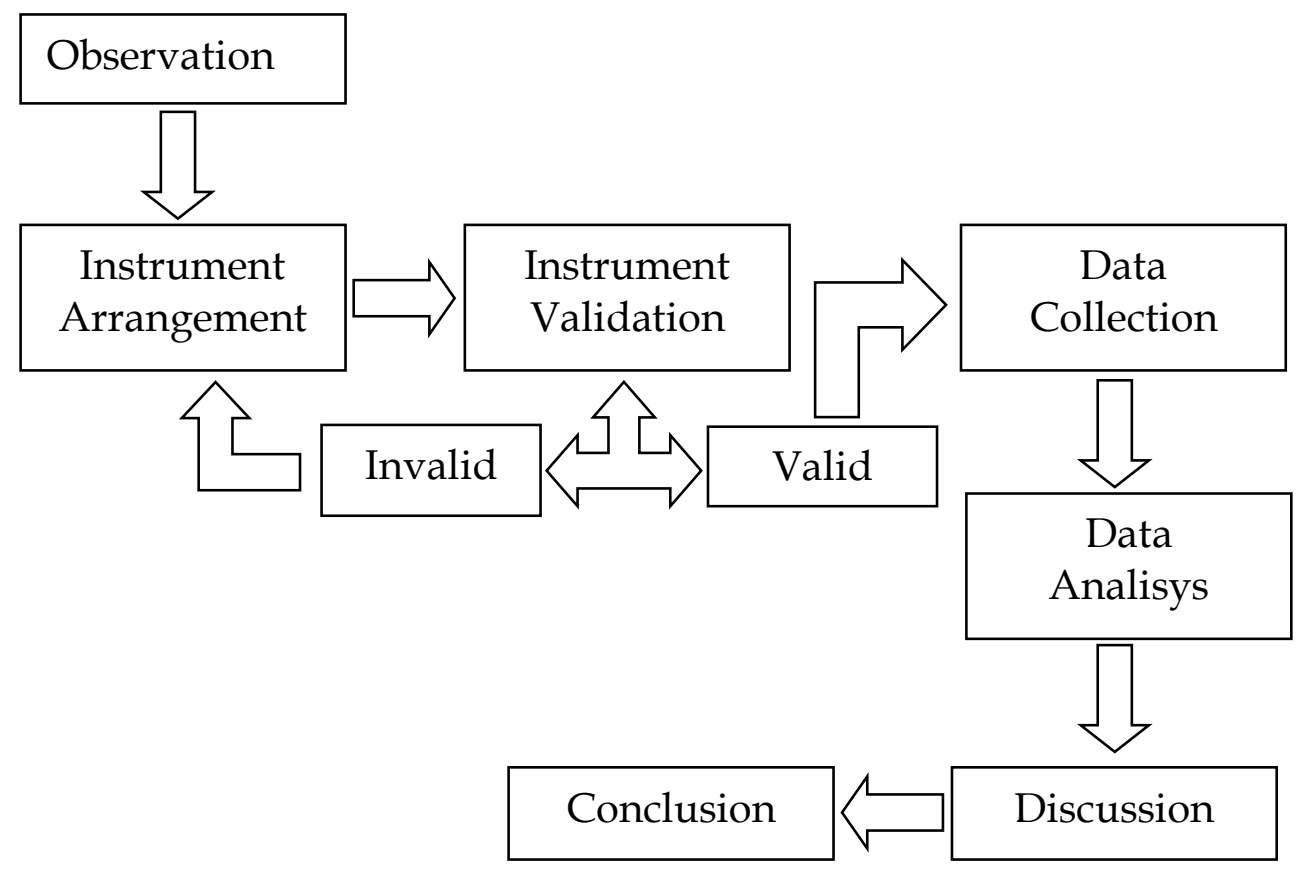

Figure 1. The research flowchart.

The research was carried out in the 2021/2022 academic year. The population of this research is the seventh-grade students of Junior High School Plus Nurul Hikmah Pamekasan which consists of 4 classes. Determination of the sample in the study was carried out randomly with several up to 20 students. The research instrument used was a test to determine students' critical thinking skills. The test is in the form of a description of 10 questions which are arranged based on indicators of critical thinking skills. The critical thinking indicators used in the research are the indicators put forward by Ennis which consist of elementary clarification, the basis for the decision, inference, advances clarification, and supposition and integration. Indicator Elementary clarification are found in questions number 1 and 2, indicator is the basis for the decision found in questions number 3 and 4. Questions number 5 and 6 are development questions with indicators inference, while questions number 7 and 8 are indicators of advances clarification. The last indicator, namely supposition and integration, is found in questions number 9 and 10. The instrument was validated by 3 validators consisting of 1 postgraduate science education lecturer and 2 science teachers. Validity test analysis was carried out using SPSS version 20 to ensure and analyze the level of validity of the instrument used based on the validation value obtained from the respondents. The basis for decision-making for instrument validity is in Table 1.

Table 1. Basic decision making for instrument validity.

\begin{tabular}{ll}
\hline Basic of decision making & Information \\
\hline R-count $>r$-Table & Valid \\
Sig $<0,005$ and positive value & Valid \\
\hline
\end{tabular}


In addition to the validity test, the instrument which is declared valid is then tested for reliability. Calculation of instrument reliability use analysis of Cronbach Alpha using SPSS version 20. The critical thinking ability test instrument is said to be reliable if the value is Cronbach Alpha > 0.6 (Utami \& Cahyono, 2020). Data on students' critical thinking skills on environmental pollution material are then analyzed based on the category of critical thinking skills contained in Table 2.

Table 2. Category of critical thinking ability.

\begin{tabular}{ll}
\hline Interpretation(\%) & Category of critical thinking ability \\
\hline $80<X \leq 100$ & Very high \\
$60<X \leq 80$ & High \\
$40<X \leq 60$ & Medium \\
$20<X \leq 40$ & Low \\
$0 \leq X \leq 20$ & Very low \\
\hline
\end{tabular}

(Ekamilasari \& Pursitasari, 2021)

\section{RESULTS AND DISCUSSION}

Critical thinking is a skill in examining assumptions or opinions, distinguishing hidden values, analyzing evidence and evaluating, and assessing final decisions (Fuad et al., 2017). Critical thinking is a high-level ability that regulates a person to be able to think logically, to prove something by way of thinking (Nurhayati et al., 2018). Based on this definition, to determine students' critical thinking skills, it is done by giving description questions that have been prepared based on critical thinking indicators that have been validated by the validator. The results of the analysis of the validity and reliability of critical thinking instruments that have been analyzed using SPSS version 20 can be seen in Table 3.

Table 3. The results of the validity analysis using SPSS.

\begin{tabular}{cccc}
\hline $\begin{array}{c}\text { Critical thinking } \\
\text { questions }\end{array}$ & r-Table & r-count & Explanation \\
\hline 1 & & 0,460 & \\
2 & & 0,751 & \\
3 & & 0,610 & \\
4 & & 0,701 & Valid \\
5 & 0,444 & 0,459 & \\
6 & & 0,751 & \\
7 & & 0,784 & \\
8 & & 0,464 & \\
10 & & 0,469 & \\
\hline
\end{tabular}

Based on the data in Table 3, shows that the value of $r$ Table is 0.444 . In all the question items shows that the value of r-count is greater than the value of r-Table, so it can be concluded that the instrument that has been developed is valid. This means that the instrument can be used to measure what it is intended to measure. In addition to the validity value, the critical thinking ability instrument was also tested for reliability to determine whether the instrument was reliable or not. The instrument reliability test using SPSS version 20 shows that the instrument's consistency over time as indicated by the coefficient value of the Cronbach Alpha more than 0.6, which is 0.799.

Students' critical thinking skills were measured using a test in the form of description questions, then analyzed individually, overall scores, each category of critical thinking, as well as the percentage per critical thinking indicator used to see the 
extent to which students' critical thinking skills were. Data on the critical thinking ability of each student is presented in Table 4 .

Table 4. The results of the value analysis of students' critical thinking skills.

\begin{tabular}{ccc}
\hline Student & Score & Category \\
\hline 1 & 37,5 & $\mathrm{~L}$ \\
2 & 77,5 & $\mathrm{H}$ \\
3 & 40 & $\mathrm{~L}$ \\
4 & 42,5 & $\mathrm{M}$ \\
5 & 52,5 & $\mathrm{M}$ \\
6 & 40 & $\mathrm{~L}$ \\
7 & 52,5 & $\mathrm{M}$ \\
8 & 20 & $\mathrm{VL}$ \\
9 & 47,5 & $\mathrm{M}$ \\
10 & 25 & $\mathrm{~L}$ \\
11 & 50 & $\mathrm{M}$ \\
12 & 52,5 & $\mathrm{M}$ \\
13 & 30 & $\mathrm{~L}$ \\
14 & 45 & $\mathrm{M}$ \\
15 & 55 & $\mathrm{M}$ \\
16 & 32,5 & $\mathrm{~L}$ \\
17 & 37,5 & $\mathrm{~L}$ \\
18 & 15 & $\mathrm{VL}$ \\
19 & 17,5 & $\mathrm{VL}$ \\
20 & 27,5 & $\mathrm{~L}$ \\
Averages score & 39,875 & $\mathrm{~L}$ \\
\hline Description: $\mathrm{VH}=$ Very High, H $=$ High, M $=$ Medium, L = Low, $\mathrm{VL}=$ Very Low
\end{tabular}

Based on the data in Table 4 we can see that there is not a single student who has a very high critical thinking ability score and there is only 1 student who has a high critical thinking ability score. Based on the data in the Table, there are 8 students with moderate critical thinking ability category, 8 low category students, and 3 students with very low critical thinking ability category. Based on the acquisition scores of 20 students in Table 4, the average critical thinking ability of students is 39.875 , which means that grade VII students of senior high school of Plus Nurul Hikmah have low critical thinking skills on environmental pollution materials. After analyzing the value of each individual's critical thinking ability, then an analysis of the achievement of each critical thinking indicator is carried out in Figure 1.

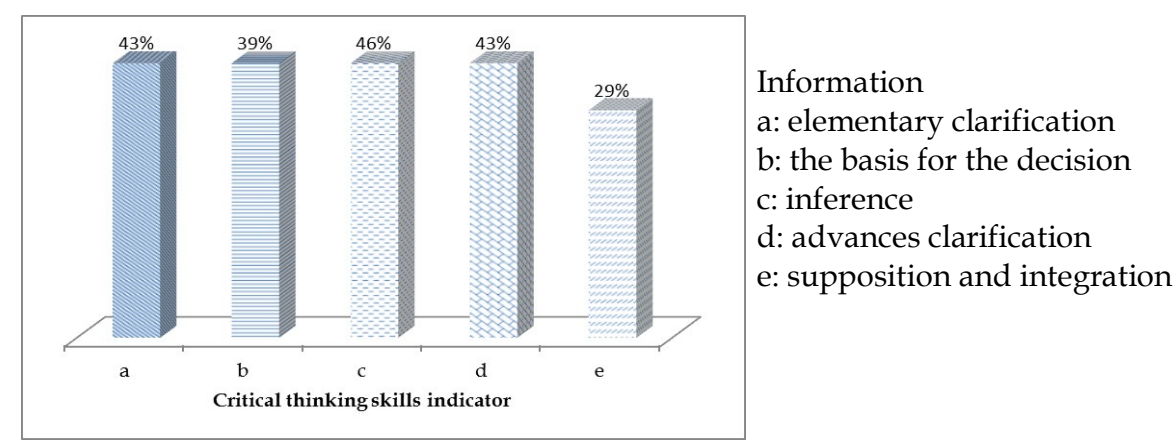

Figure 2. Analysis of the achievement of critical thinking indicators.

Based on Figure 2, it can be seen the percentage of students' critical thinking abilities on each indicator. The third indicator, namely inference, shows the highest value among the other 4 indicators with a percentage of $46 \%$. This can be seen in the example 
questions with indicators inference in Figure 2.

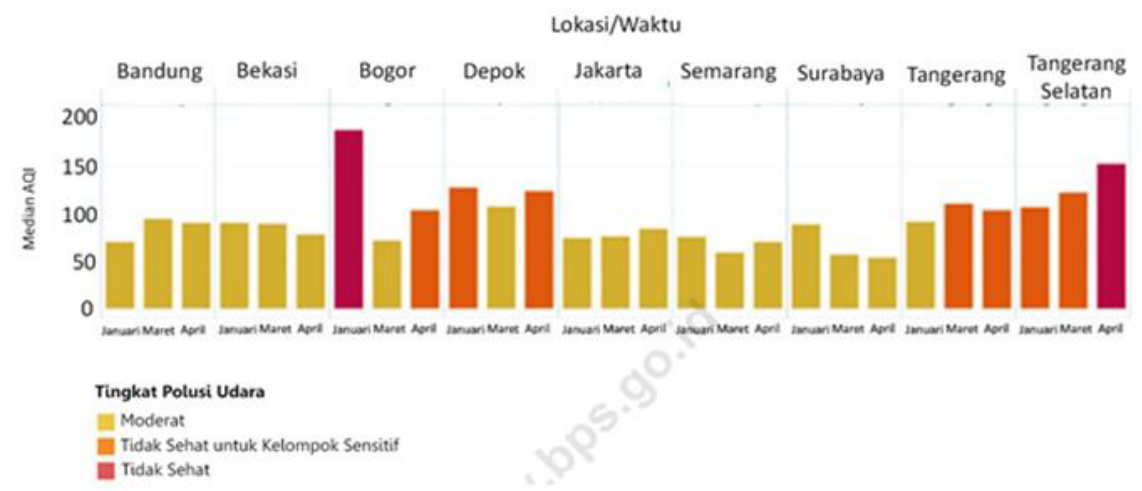

Gambar di atas menunjukkan grafik tingkat polusi udara pada masa pandemi Covid-19 tahun 2020 di beberapa kota besar di Indonesia.

- Berdasarkan grafik tersebut identifikasi kota mana yang mengalami kenaikan tingkat polusi udara dan kota mana yang mengalami penurunan tingkat polusi udara?

- Jika kalian boleh memilih kota mana saja yang aman untuk ditempati selama tahun tersebut? Berilah alasannya!

Figure 3. Examples of critical thinking questions on inference indicator.

The ability of individuals to make conclusions based on several statements is called inference (Benjamin et al., 2021). Based on Figure 2, we can see that some students have been able to make deductions and inductions in considering the results, and can make and determine their considerations to live in a certain place based on the graphs in the questions, although they are still in the low category. This stage requires an analysis of the concept of environmental pollution to consider whether or not an area is safe if it is occupied. Students' ability to conclude or make generalizations can be trained by applying the concepts, principles, and skills they have learned to solve the problems they face (Fakhriyah, 2014). Contrary to the indicator inference, the last indicator, namely supposition and integration, shows the lowest value than other critical thinking indicators with a value of $29 \%$. Examples of questions with indicators supposition and integration can be seen in Figure 3.
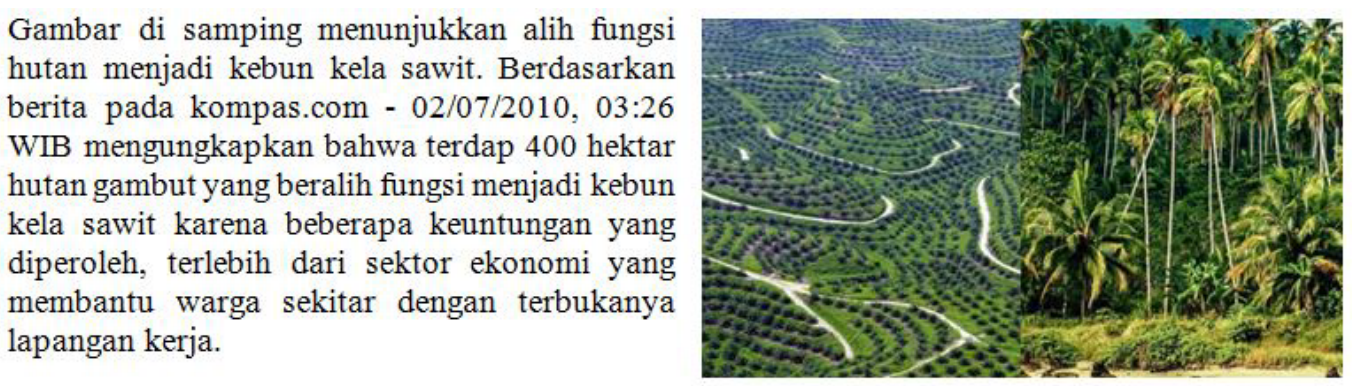

Berdasarkan gambar dan wacana di atas, berkaitan dengan konsep lingkungan, setujukah anda terhadap rencana alih fungsi hutan menjadi kebun kelapa sawit? Kemukakan alasannya!

Figure 4. The examples of critical thinking questions with supposition and integration indicator.

Based on Figure 2 shows that the supposition and integration indicator have the lowest percentage in the very low category, which means that most students have not been able to combine information or integrate it in making decisions and considering reasons well (Safitri and Prasi, 2020). The basic ability of students in the first indicator 
still shows a moderate category with a percentage value of $43 \%$, so that the ability of students to decide on an action or integrate and combine is still low. Lack of basic knowledge of students makes students feel doubtful in integrating, connecting or taking certain actions. Critical reading activities such as an example of news discourse contained in questions can be a way to train students to combine and integrate various concepts. The result of student scores on these indicators is one of the factors causing low critical thinking skills.

The low critical thinking ability of students is influenced by several factors. One of the causes of students' low critical thinking is that the types of assessment instruments that are often used by teachers are still limited to $\mathrm{C} 1$ (memorization) and C2 (understanding) based on the cognitive domain of Bloom's taxonomy (Amalia \& Susilaningsih, 2014). The type of instrument that is still dominated by low-level operational verbs based on Bloom's taxonomy cannot train students' critical thinking skills (Ekamilasari \& Pursitasari, 2021). Several types of questions with C1 and C2 domains, the content of the questions allows students to see clearly what is being asked in the question, so that students do not have the opportunity to analyze and think more deeply about the existing questions and their relation to the answers. Therefore, to help students develop their critical thinking skills, they need practice questions in the form of questions that contain elements of a higher cognitive domain than C1 and C2.

In addition, based on interviews conducted by researchers with one of the SMP Plus teachers, Nurul Hikmah stated that there are still many teachers who use the one-way learning model during teaching and learning activities, so students do not have full opportunities to explore their ideas. The selection of the right learning model to train students' critical thinking skills is very important so that students not only act as recipients of information but also can think at higher levels such as critical thinking (Muttaqiin \& Sopandi, 2016). The questions developed by the researcher contain several types of questions that require the ability to analyze reading. The lack of student interest in reading also causes critical thinking skills to be low (Wakhidah, 2018). Reading is one of the keys to gaining knowledge. The low interest in reading will have a negative effect on knowledge (which in this case is the science field).

Science learning until now has become a learning that is considered difficult and even tends to be avoided by students (Ichsan, 2020). Environmental pollution material is one of the sub-materials in science, so this material is also one that students avoid. Students who tend to avoid lessons will find it difficult to be motivated to develop their thinking skills. In addition, the low critical thinking ability of students can also be caused by the teaching materials used. Teachers in general in schools only use textbooks from the government and LKS as learning resources (Latifah et al., 2020). Each student in each institution has different characteristics. The needs of students in each institution are also different, the facilities and infrastructure provided by each institution are also different (Agustin et al., 2021).

Differences in student characteristics can only be recognized by educators who are responsible for these students, so they can create a learning atmosphere and learning resources according to the needs and characteristics of students to help students improve their critical thinking skills. The module is an alternative that can be used to develop students' critical thinking skills (Diana \& Sukestiyarno, 2019). The module has five main characteristics that become its advantages, namely self-instructional (facilitates independent learning), self-contained (loads all material), stand-alone (does not depend on other teaching materials), adaptive, and user-friendly (easy to use) 
(Kimianti \& Prasetyo, 2019). Modules that are packaged electronically following the development of the industrial revolution 4.0 era can be one way to improve student's critical thinking skills because e-modules can be prepared by each teacher according to the characteristics of the material and the needs of their students (Nikita et al., 2018).

\section{CONCLUSION}

Based on the results of the research, the achievement of critical thinking skills in the first indicator of elementary clarification obtained a higher score than the second indicator based on the decision, while the third inference indicator obtained the highest score among other indicators. The fourth indicator of advances clarification scores exactly the same as the first indicator, while the fifth indicator of supposition and integration gets the lowest score compared to the other indicators. In general, students' critical thinking skills on all indicators are in the low category. There is an influence of the type of assessment instrument used, the selection of learning models, the selection of teaching materials used on students' critical thinking skills. Furthermore, it is necessary to conduct research on the development of ESD-based modules to improve students' critical thinking skills.

\section{REFERENCES}

Agustin, N., Mardati, A., Sukma, H. H., Martaningsih, S. T., \& Maryani, I. (2021). Peran guru dalam membentuk karakter siswa. Yogyakarta: UAD press.

Amalia, N. F., \& Susilaningsih, E. (2014). Pengembangan instrumen penilaian keterampilan berpikir kritis siswa SMA pada materi asam basa. Jurnal Inovasi Pendidikan Kimia, 8(2), 1380-1389. https://doi.org/10.15294/jipk.v8i2.4443

Arikunto, S. (2013). Prosedur penelitian: Pendekatan praktis. Jakarta: Rekanika Cipta.

Benjamin, B., Qohar, A., \& Sulandra, I. M. (2021). Analysis of critical thinking ability of class x high school students in solving SPLTV problems. Scholar's Journal: Journal of Mathematics Education, 5(2), 909-922. https://doi.org/10.31004/cendekia.v5i2.574

Diana, N., \& Sukestiyarno. (2019). Analisis kemampuan berpikir kritis siswa dalam pembelajaran mandiri berbasis e-modul. Seminar Nasional Pascasarjana 2019, 2010(1), 203206.

Ekamilasari, \& Pursitasari, I. D. (2021). Students' critical thinking skills and sustainability awareness in science learning for implementation education for sustainable development. Indonesian Journal of Multidiciplinary Research Journal, 1(1), 121-124.

Fakhriyah, F. (2014). Penerapan problem-based learning dalam upaya mengembangkan kemampuan berpikir kritis mahasiswa. Jurnal Pendidikan IPA Indonesia, 3(1), 95-101. https:// doi.org/10.15294/jpii.v3i1.2906

Fuad, N. M., Zubaidah, S., Mahanal, S., \& Suarsini, E. (2017). Improving junior high schools' critical thinking skills based on test three different models of learning. International Journal of Instruction, 10(1), 101-116. https:/ / doi.org/10.12973/iji.2017.1017a

Ichsan, A. S. (2020). Pengembangan bahan ajar membaca berbasis pendekatan kontekstual. Magistra: Jurnal Keguruan dan Ilmu Pendidikan, 7(2), 98-114.

Kartika, K. A., Eftiwin, L., Fitri, F. M., \& Walid, A. (2020). Profil kemampuan berpikir kritis siswa kelas viii smp pada mata pelajaran ipa. Jartika: Jurnal Riset Teknologi dan Inovasi Pendidikan, 3(1), 1-10. https:// doi.org/10.36765/jartika.v3i1.46

Kimianti, F., \& Prasetyo, Z. K. (2019). Pengembangan e-modul ipa berbasis problem based learning untuk meningkatkan literasi sains siswa. Kwangsan: Jurnal Teknologi Pendidikan, 7(2), 91-99. https://doi.org/10.31800/jtp.kw.v7n2.p91--103

Latifah, N., Okyranida, I. Y., \& Setiadi, A. (2020). Pengembangan modul ipa terpadu problembased learning (PBL) dengan tema energi sebagai sumber kehidupan SMP/MTs. Jurnal Ilmiah Mahasiswa Pendidikan Fisika, 1(1), 1-6. 
Luzyawati, L. (2018). Analisis kemampuan berpikir kritis siswa sma materi alat indera melalui model pembelajaran inquiry pictorial riddle. Edu Sains: Jurnal Pendidikan Sains dan Matematika, 5(2), 9-15. https://doi.org/10.23971/eds.v5i2.732

Muttaqiin, A., \& Sopandi, W. (2016). Pengaruh model discovery learning dengan sisipan membaca kritis terhadap kemampuan berpikir kritis siswa. Edusains, 8(1), 57-65. https://doi.org/10.15408/es.v8i1.1752

Nikita, P., Lesmono, A., \& Harijanto, A. (2018). Pengembangan e-modul materi fluida dinamis untuk meningkatkan kemampuan berpikir kritis siswa SMA kelas XI. Jurnal Pembelajaran Fisika, 7(2), 175-180. https://doi.org/10.19184/jpf.v7i2.7925

Nurhayati, Munawaroh, F., \& Wulandari, A. Y. R. (2018). Analisis kemampuan berpikir kritis pada implementasi model pembelajaran susan loucks horsley. Senco Proceedings - Science Education, 2018(1), 39-52.

Nurlailah, S., \& Hamdu, G. (2021). Implementasi assessment sikap berpikir kritis berbasis education for sustainable development (ESD) di sekolah dasar. Jurnal Ideas: Pendidikan, Sosial, dan Budaya, 7(3), 309. https://doi.org/10.32884/ideas.v7i3.390

Nuryanti, L., Zubaidah, S., \& Diantoro, M. (2018). Analisis kemampuan berpikir kritis siswa smp. Jurnal Pendidikan: Teori Penelitian dan Pengembangan, 3(2), 155-158. Retrieved from http://dx.doi.org/10.17977/jptpp.v3i2.10490

Pradana, S. D. S., Parno, P., \& Handayanto, S. K. (2017). Pengembangan tes kemampuan berpikir kritis pada materi optik geometri untuk mahasiswa fisika. Jurnal Pendelitian dan Evaluasi Pendidikan, 21(1), 51-64. https://doi.org/10.21831/pep.v21i1.13139.

Rahman, A., \& Nuryana, Z. (2019). Pendidikan islam di era revolusi industri 4.0. Depok: Komojoyo Press

Ridho, S., Ruwiyatun, R., Subali, B., \& Marwoto, P. (2020). Analisis kemampuan berpikir kritis siswa pokok bahasan klasifikasi materi dan perubahannya. Jurnal Penelitian Pendidikan IPA, 6(1), 10-15. https:// doi.org/10.29303/jppipa.v6i1.194

Safitri, A. N. R., \& Prasti, I. G. N. (2020). Analisis hubungan motivasi belajar terhadap keterampilan berpikir kritis mahasiswa pada pokok bahasan dinamika partikel. Jurnal Kependidikan Betara, 1(2), 48-55.

Santos, L. F. (2017). The role of critical thinking in science education. Journal of Education and Practice, 8(20), 159-173.

Shohib, M., Rahayu, Y.S., \& Hariyono, E. (2021). Scientific literacy ability of junior high school students on static electricity and electricity in living things. IJORER: International Journal of Recent Educational Research, 2(6), 700-708. https://doi.org/10.46245/ijorer.v2i6.170

Suciono, W., Rasto, R., \& Ahman, E. (2021). Analisis faktor-faktor yang mempengaruhi keterampilan berpikir kritis siswa dalam pembelajaran ekonomi era revolusi 4.0. SOCIA: Jurnal Ilmu Sosial, 17(1), 48-56. https:/ / doi.org/10.21831/socia.v17i1.32254

Susilawati, E., Agustinasari, A., Samsudin, A., \& Siahaan, P. (2020). Analisis tingkat keterampilan berpikir kritis siswa sma. Jurnal Pendidikan Fisika dan Teknologi, 6(1), 11-18. https://doi.org/10.29303/jpft.v6i1.1453

Syahrul, R., Sumarmin, R., Hellendra, H., \& Yogica, R. (2021). Analisis berpikir kritis siswa sman 4 padang pada materi pencemaran lingkungan. Jurnal Eksakta Pendidikan (JEP), 5(1), 25-32. https://doi.org/10.24036/jep/vol5-iss1/565

Utami, B., Saputro, S., Ashadi, A., Masykuri, M., \& Widoretno, S. (2017). Critical thinking skills profile of high school students in learning chemistry. International Journal of Science and Applied Science: Conference Series, 1(2), 124-130. https://doi.org/10.20961/ijsascs.v1i2.5134

Utami, Y. P, \& Cahyono, D. A. D. (2020). Study at home: Analisis kesulitan belajar matematika pada proses pembelajaran daring. Jurnal Ilmiah Matematika Realistik, 1(1), 20-26. https://doi.org/10.33365/ji-mr.v1i1.252

Wakhidah, N. (2018). Pembelajaran dengan pendekatan saintifik terhadap kemampuan berpikir kritis mahasiswa calon guru madrasah ibtidaiyah. Premiere Educandum: Jurnal Pendidikan Dasar dan Pembelajaran, 8(2), 150-156. https://doi.org/10.25273/pe.v8i2.2950 


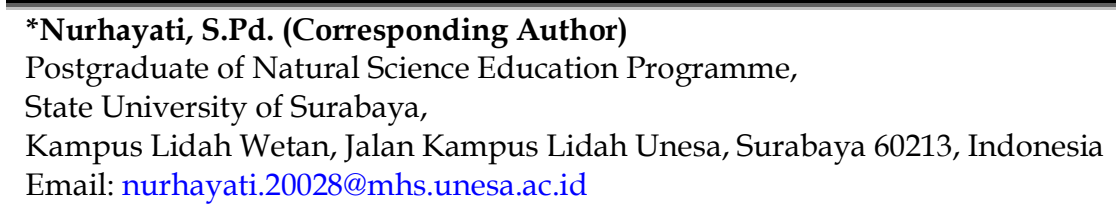

Prof. Dr. Hj. Rudiana Agustini, M.Pd.

Postgraduate of Natural Science Education Programme,

State University of Surabaya,

Kampus Lidah Wetan, Jalan Kampus Lidah Unesa, Surabaya 60213, Indonesia

Email: rudianaagustini@unesa.ac.id

\section{Dr. Elok Sudibyo, M.Pd.}

Postgraduate of Natural Science Education Programme,

State University of Surabaya,

Kampus Lidah Wetan, Jalan Kampus Lidah Unesa, Surabaya 60213, Indonesia

Email: eloksudibyo@unesa.ac.id 